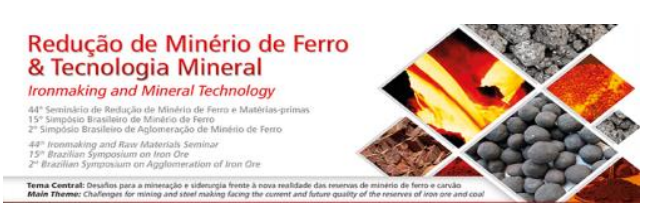

\title{
FROM IRON ORE TO IRON*
}

Alim Ullah

Raymond Martin²

Wolf-Dieter Kunst ${ }^{3}$

\begin{abstract}
The paper discusses the necessity of upgrading low-iron containing ores, giving as an example, NML-Tata Steel Project in the Quebec-Labrador region of Canada. As cooling of pellets is generally a bottle-neck in most pelletizing plants, examples are given of the methods used to improve cooling in the existing plants and a simple, low-cost alternative, tested on a pot-grate system, is presented. The procedure described is applicable to sinter plants also. The trends in iron and steel production worldwide are then given, as well as the reasons for the increase in steel production by the Electric Arc Furnace (EAF) route. The stoichiometric and thermodynamic requirements for producing iron, irrespective of the process, are explained. The different ironmaking processes, especially the Direct Reduction (DR) ones are briefly discussed, outlining recent improvements made to some of them. The pros and cons of producing cooled DRI and Hot-Briquetted Iron ( $\mathrm{HBI})$ are given with predictions made for their future growth. An alternative to cold-briquetting of DRI fines is also discussed. Highlights of an ironmaking processes which is at the laboratory/pilot plant stage are given.
\end{abstract}

Keywords: Iron ores; Pelletizing; Direct reduction.

\footnotetext{
* Technical contribution to the $44^{\text {th }}$ Ironmaking and Raw Materials Seminar, $15^{\text {rd }}$ Brazilian Symposium on Iron Ore and $2^{\text {nd }}$ Brazilian Symposium on Agglomeration of Iron Ore, September $15^{\text {th }}$ to $18^{\text {th }}$, 2014, Belo Horizonte, MG, Brazil.
} 


\section{INTRODUCTION}

As the iron content in ores is decreasing, it is necessary to increase it in order to be used for ironmaking. Iron ore fines with appropriate iron content are generally used for producing sinters or pellets.

Because of the reversible nature of conversion of iron oxide to iron, there will always be some unused $\mathrm{H}_{2}$ and $\mathrm{CO}$ in the off-gas, irrespective of the process used.

It is likely that production of steel via the Electric Arc Furnace (EAF) route will continue to grow at a faster rate than by the Blast Furnace (BF) route in most regions. As many mini-mills use Direct Reduced Iron (DRI) as part of their feed material, especially to produce high-quality steel, DRI production will also increase rapidly.

In addition to the two main Direct Reduction (DR) processes, namely Midrex and HyL/Energiron and smelting processes like Corex, other newer smelting processes are being developed.

\section{BENEFICIATION OF IRON ORES}

With the rapid depletion of high iron containing ores, beneficiation of low quality ores is becoming increasingly more important. Many of these mines are located in remote regions with harsh climatic conditions. One such project under development is the New Millennium Iron /Tata Steel (NMI/TS) Project in the Quebec-Labrador region of Canada. The project envisages production of concentrates and both Blast Furnace (BF) and DR pellets. The major strengths of this multi-billion dollar project are a very large reserve of ores and internal use of both concentrate and BF pellets by Tata Steel. Although a bankable Feasibility Study has been completed by an international engineering company, the details have not been made public yet. However, Table 1 lists the key figures reproduced from NMI Press Release 14-04 of March 27, 2014. The Project comprises two properties: KéMag mines in Quebec and LabMag mines in Newfoundland \& Labrador. The reserves given are for the combined mines, whereas the difference in dollar figures is because they are given for the two different routes. The Capex for KéMag Project is higher, with slightly lower operating costs.

Table 1. Key Figures of NMI/TS Project

\begin{tabular}{l|l|l|l}
\hline & Mt & $\%$ Fe & CA $\$$ \\
\hline Proven Reserves & 4,057 & 30.3 & \\
\hline Probable Reserves & 1,243 & 30.5 & \\
\hline Capex, Millions & & & $7,749-8,239$ \\
\hline Cost, t Concentrate & & & $42.55-43.03$ \\
\hline Cost, \$/Pellet & & & $51.59-52.22$ \\
\hline NPV@ 30\% Equity, Millions & & & $2,697-3,303$ \\
\hline
\end{tabular}

The schematic shown in Figure 1 is reproduced from the Prefeasibility Study Report prepared by BBA Inc. for the KéMag Property in February 2009 [1]. The flow sheet for the new project will be very similar.

\section{PELLETIZING}

The bulk of pellets is produced by either a straight grate system or a grate-kiln system. The purpose here is not to discuss the pros and cons of each system but to outline a general problem facing many pelletizing plants. Generally speaking, cooling

\footnotetext{
* Technical contribution to the $44^{\text {th }}$ Ironmaking and Raw Materials Seminar, $15^{\text {rd }}$ Brazilian Symposium on Iron Ore and $2^{\text {nd }}$ Brazilian Symposium on Agglomeration of Iron Ore, September $15^{\text {th }}$ to $18^{\text {th }}$, 2014, Belo Horizonte, MG, Brazil.
} 
is usually the bottleneck in most pelletizing plant, taking up approximately $35 \%$ of the cycle time. Some of the methods used in various operating plants are:

- Use of external coolers as used by Ferteco, Essar, LKAB and Kobe

- Increase fan capacity by having more than one cooling fans.

- Increasing bed height, the optimum value found by trial-and-error, has also been used.

\subsection{Alternative Cooling Method}

A simple and inexpensive method of cooling would be the use of atomized water, the water particles being in micron size. The procedure had been tested at the COREM facilities in Quebec City, Canada in 2008 with very positive results. A schematic of the pot-grate test facility used is shown in Figure 2. Water was introduced with the average bed temperature at approximately $800^{\circ} \mathrm{C}$ and stopped when the bottom bed temperature reached $150^{\circ} \mathrm{C}$. The summary of results is given in Table 2 .

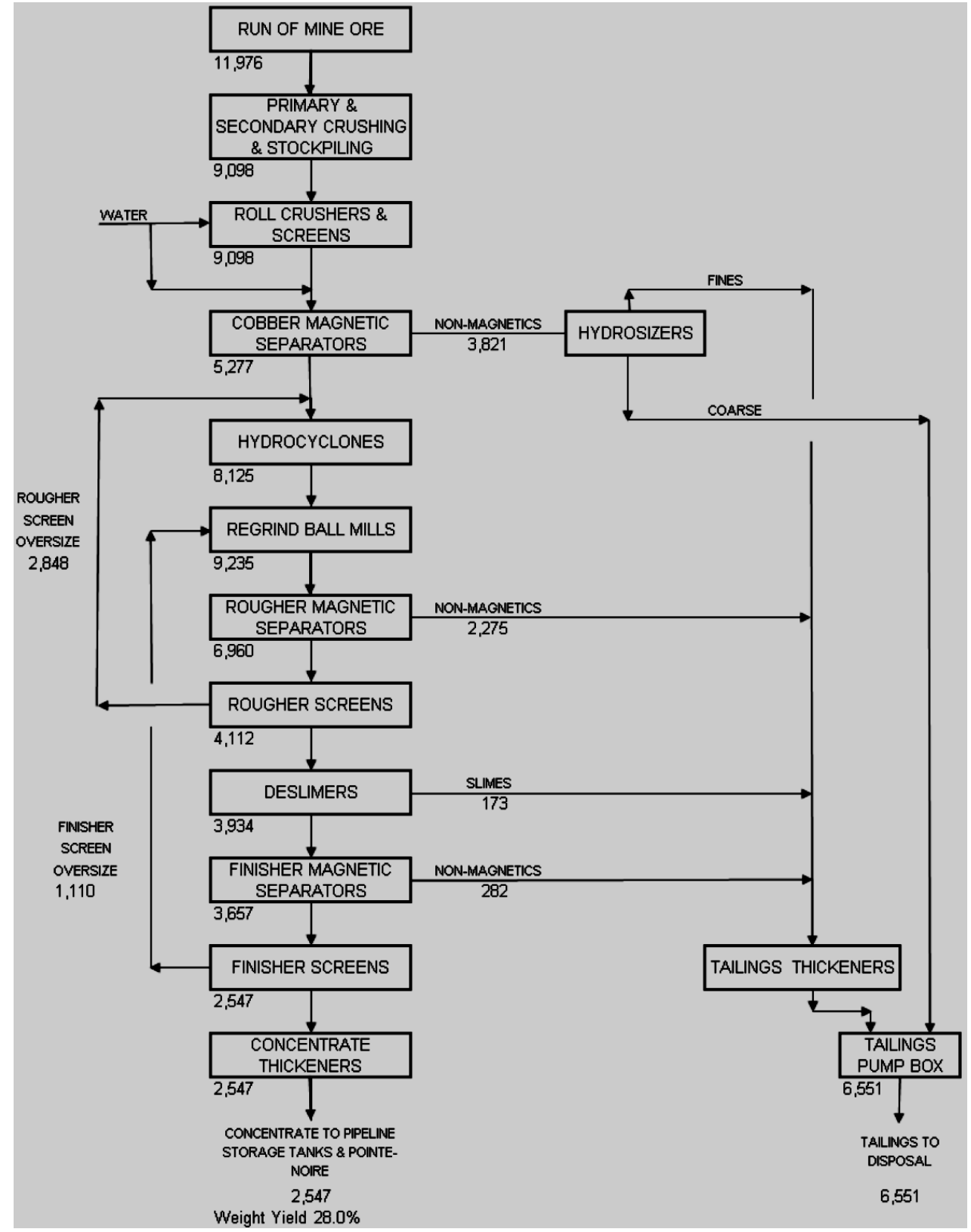

Figure 1. Concentrator Flow Diagram for KeMag [1]

* Technical contribution to the $44^{\text {th }}$ Ironmaking and Raw Materials Seminar, $15^{\text {rd }}$ Brazilian Symposium on Iron Ore and $2^{\text {nd }}$ Brazilian Symposium on Agglomeration of Iron Ore, September $15^{\text {th }}$ to $18^{\text {th }}$, 2014, Belo Horizonte, MG, Brazil. 


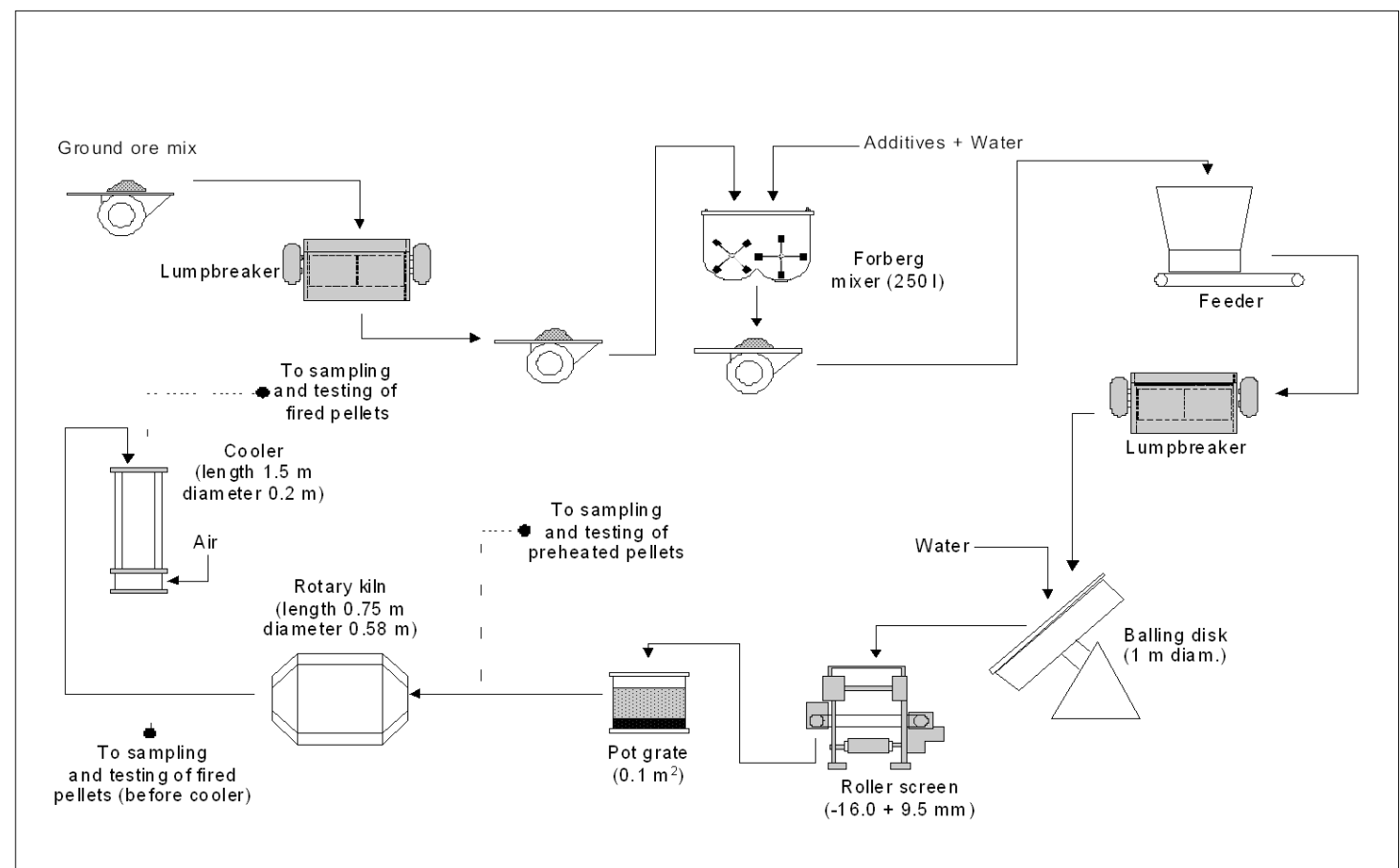

Figure 2. Pot-Grate test Facility at COREM

The application would be much simpler in an industrial plant in which atomized water would be used continuously. The best region would be in the $400^{\circ} \mathrm{C}$ to $200^{\circ} \mathrm{C}$ range. There is absolutely no danger of doing any damage to equipment, if water is introduced in very small increments and careful evaluation of results is made before the next increment.

Table 2: Results of Pot-Grate Tests at COREM

\begin{tabular}{l|l|l|l|l|l|l|l|l}
\hline $\begin{array}{l}\text { Test } \\
\#\end{array}$ & Water & \multicolumn{2}{|l|}{$\begin{array}{l}\text { Air Flow, } \\
\mathrm{Nm}^{3} / \mathrm{h}\end{array}$} & \multicolumn{3}{|l|}{ Top of Bed, ${ }^{\circ} \mathrm{C}$} & Diff., ${ }^{\circ} \mathrm{C}$ & \multicolumn{2}{l|}{$\begin{array}{l}\text { Average of Bed, } \\
\text { oC }\end{array}$} & Diff., ${ }^{\circ} \mathrm{C}$ \\
\hline & & & Initial & Final & & Initial & Final & \\
\hline 2C & No & 145.1 & 1028.3 & 57.2 & 971.1 & 1046.2 & 50.5 & 995.7 \\
\hline 2B & Yes & 137.2 & 1154.6 & 33.6 & 1121.0 & 1158.7 & 25.7 & 1132.4 \\
\hline Gain & & & & & 149.9 & & & 136.7 \\
\hline 2D & No & 119.7 & 1062.7 & 261.6 & 801.1 & 1081.2 & 115.7 & 965.5 \\
\hline 2E & Yes & 124.9 & 1145.3 & 124.4 & 1020.9 & 1143.9 & 57.3 & 1086.6 \\
\hline Gain & & & & & 219.8 & & & 121.1
\end{tabular}

Because of inherent difference in processing, the initial conditions for cooling tests with and without water are not identical. Nevertheless, the results clearly indicate improved cooling with atomized water, evidenced by the higher temperature difference, $1121^{\circ} \mathrm{C}$ with water and $971.1^{\circ} \mathrm{C}$ without (2C and 2B). In practical terms, this signifies use of lower flow rate of cooling air with associated savings in electricity consumption. A heat balance at a specific site has to be carried out to determine the effect of evaporative cooling but savings are likely to arise because of (1) heat recovered from pellets and (2) less heat loss through the stack because of lower flow rate.

The procedure described will be applicable to sinter plants also.

\footnotetext{
* Technical contribution to the 44 $4^{\text {th }}$ Ironmaking and Raw Materials Seminar, $15^{\text {rd }}$ Brazilian Symposium on Iron Ore and $2^{\text {nd }}$ Brazilian Symposium on Agglomeration of Iron Ore, September $15^{\text {th }}$ to $18^{\text {th }}$, 2014, Belo Horizonte, MG, Brazil.
} 


\section{IRONMAKING}

Table 3 shows the world production of crude steel, Electric Arc Furnace (EAF) steel and DRI from years 2000 to 2012. Production of crude steel increased by $81.73 \%$ from 2000 to 2012, EAF steel by $56.76 \%$ and DRI by $62.18 \%$ during the same period. This signifies that EAF steel producers are using more virgin iron units and are moving into production of higher quality steel [2].

Table 3: Production of Steel and DRI

\begin{tabular}{l|l|l|l|l|l}
\hline Year & 2000 & 2001 & 2002 & 2003 & 2004 \\
\hline $\begin{array}{l}\text { Crude Steel, } \\
\text { Mt }\end{array}$ & 850,156 & 852,173 & 905,155 & 971,016 & $1,062,541$ \\
\hline EAF Steel, Mt & 287,389 & 285,110 & 304,890 & 324,442 & 353,365 \\
\hline DRI, Mt & 43,740 & 40,091 & 45,079 & 48,828 & 55,157 \\
\hline
\end{tabular}

\begin{tabular}{c|c|c|c|c|c|c|c|c}
\hline Year & 2005 & 2006 & 2007 & 2008 & 2009 & 2010 & 2011 & 2012 \\
\hline CS, Mt & $1,147,772$ & $1,250,473$ & $1,348,122$ & $1,342,625$ & $1,237,044$ & $1,432,750$ & $1,536,966$ & $1,545,011$ \\
\hline EAF, Mt & 365,460 & 395,896 & 430,330 & 428,209 & 354,863 & 419,263 & 451,089 & 450,512 \\
\hline DRI, Mt & 57,710 & 59,175 & 66,370 & 66,044 & 64,452 & 70,015 & 70,900 & 70,937 \\
\hline
\end{tabular}

\subsection{Some Fundamentals}

The overall reaction of reduction of $\mathrm{Fe}_{2} \mathrm{O}_{3}$ to $\mathrm{Fe}$ occurs according to the reaction given below:

$$
\mathrm{Fe}_{2} \mathrm{O} 3+3 \mathrm{H} 2 \leftarrow------\rightarrow 2 \mathrm{Fe}+3 \mathrm{H}_{2} \mathrm{O}(\mathrm{g}) \quad \Delta \mathrm{H}_{298}{ }^{\circ} \mathrm{K}=25,106 \mathrm{kcal}
$$

This reversibility implies that there will always be some unused $\mathrm{H}_{2}$ (and $\mathrm{CO}$ ) in the reactor off-gas and the overall efficiency of the process will depend largely on how well this off-gas is used.

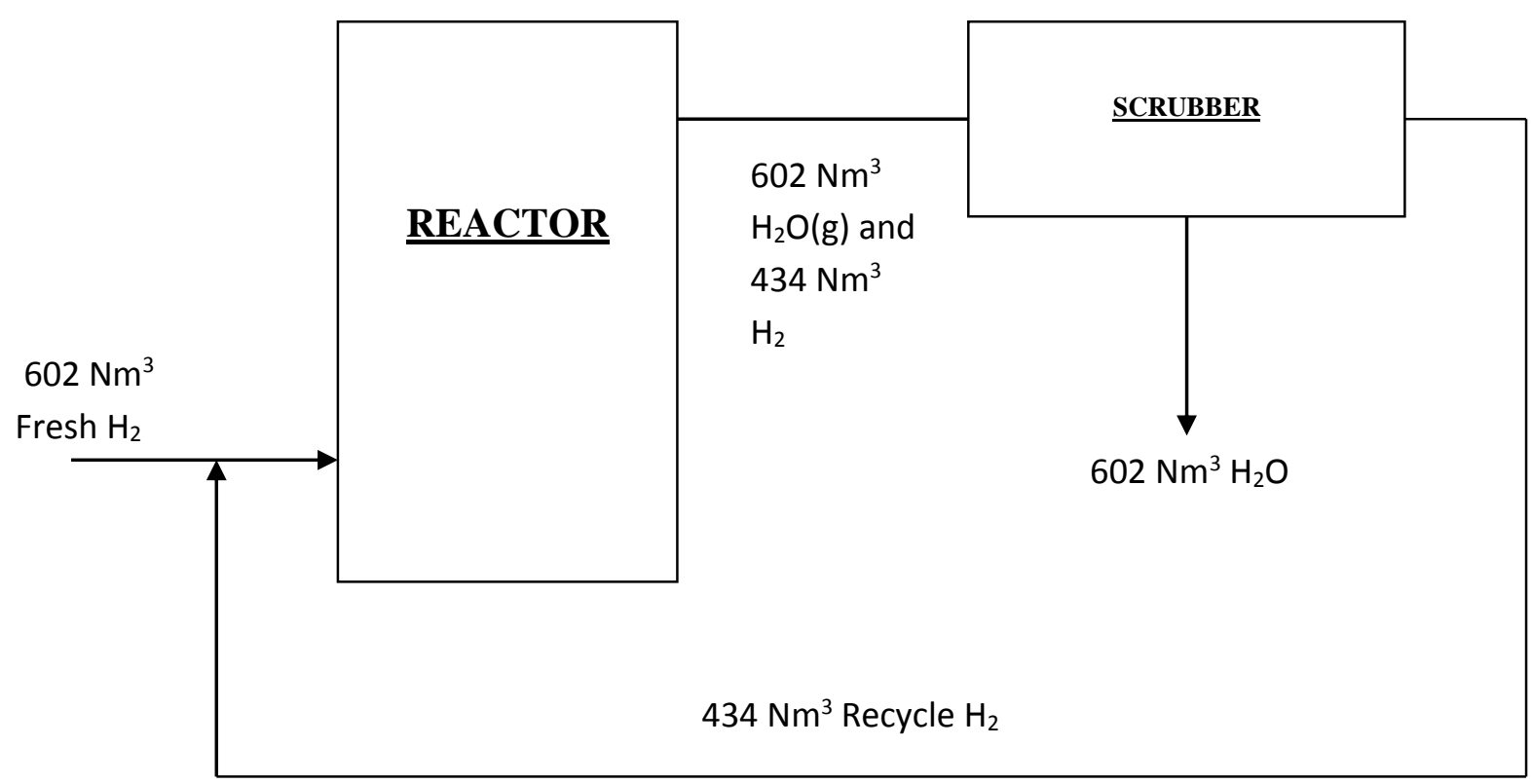

Figure 3: Reduction of $\mathrm{Fe}_{2} \mathrm{O}_{3}$ with $\mathrm{H}_{2}$

The example shown above is for the reduction of with $100 \% \mathrm{H}_{2}$ at a temperature of $927^{\circ} \mathrm{C}$. The minimum or stoichiometric requirement of pure $\mathrm{H}_{2}$ is $602 \mathrm{Nm}^{3}$ but the

\footnotetext{
* Technical contribution to the $44^{\text {th }}$ Ironmaking and Raw Materials Seminar, $15^{\text {rd }}$ Brazilian Symposium on Iron Ore and $2^{\text {nd }}$ Brazilian Symposium on Agglomeration of Iron Ore, September $15^{\text {th }}$ to $18^{\text {th }}$, 2014, Belo Horizonte, MG, Brazil.
} 
thermodynamic requirement brings it up to $1036 \mathrm{Nm}^{3}$. In a once-through system, the total gas requirement has to be supplied by the gas producer (generally a reformer), whereas in a completely closed-loop system only $602 \mathrm{Nm}^{3}$ of fresh $\mathrm{H}_{2}$ has to be supplied. Initially HyL was a once-through system but the latest plants come close to being a closed-loop system. However, a completely closed-loop is not feasible because of loss of pressure control and $\mathrm{N}_{2}$ build-up. Midrex, on the other hand, always recycled some off-gas through its reformer, but can improve its efficiency by recycling more of this off-gas. Approximately $33 \%$ of the off-gas is used as combustibles in a typical Midrex Plant.

\subsection{DRI vs HBI}

Table 3: Comparison of DRI and HBI

\begin{tabular}{l|ll}
\hline & HBI & DR! \\
\hline Characteristics & $\begin{array}{l}\text { Less pyrophoric, higher bulk } \\
\text { density, more difficult to handle } \\
\text { because of sharp edges }\end{array}$ & $\begin{array}{l}\text { Can be pyrophoric, especially } \\
\text { at low temperature operation }\end{array}$ \\
\hline Market & Generally exported & Generally consumed internally \\
\hline C in Product & Lower & Can be as high as 3.5\% \\
\hline Production & $100 \%$ & $\sim 110-115 \%$ \\
\hline Capital Cost & $100 \%$ & $\sim 90-95 \%$ \\
\hline Natural Gas & $100 \%$ & $\sim 85-90 \%$ \\
\hline Price of Product & $100 \%$ & $\sim 85-95 \%$ \\
\hline$\%$ Product at $50 \%$ Price & $0 \%$ & $\sim 5 \%$ \\
\hline
\end{tabular}

$\mathrm{HBI}$ production was started to prevent reoxidation of DRI by compacting the material at high temperatures. This reduces the porosity of DRI and makes the material more inert. A similar effect, albeit to a smaller degree, is achieved by processing at high temperatures, as is being done in all DR plants now. DRI from rotary kiln plants is usually inert as it is processed at much higher temperatures than the shaft furnace processes. This means is that, notwithstanding International Maritime Organization's classification, more and more DRI will be transported from one location to another. This is verified by DRI/HBI shipments given In Midrex's 2012 DR Statistics [3]. Table 4 lists these values.

Table 4: DRI and HBI Shipments

\begin{tabular}{l|l|l|l|l|l|l|l}
\hline Year & 2006 & 2007 & 2008 & 2009 & 2010 & 2011 & 2012 \\
\hline DRI, Mt & 7.81 & 10.82 & 8.01 & 8.50 & 8.42 & 7.97 & 8.17 \\
\hline $\mathrm{HBI}, \mathrm{Mt}$ & 6.75 & 6.24 & 5.99 & 5.38 & 5.60 & 6.06 & 6.58 \\
\hline
\end{tabular}

The data presented indicate clearly that DRI shipments are the major contributor to all shipments and will continue to play an important role in the long distance transport of DR products.

Transport of hot DRI to the adjacent melt shop is becoming increasingly important because of substantial savings in electricity consumption. However, a buffer is needed when the melt shop cannot receive hot DRI and hot-briquetting is an option. The other option is to send the hot DRI o an external cooler.

It is likely that fewer HBI plants will be built as merchant plants, because DRI can also be transported safely, if "passivated" properly. Use of external coolers will also reduce the demand for hot-briquetting.

\footnotetext{
* Technical contribution to the $44^{\text {th }}$ Ironmaking and Raw Materials Seminar, $15^{\text {rd }}$ Brazilian Symposium on Iron Ore and $2^{\text {nd }}$ Brazilian Symposium on Agglomeration of Iron Ore, September $15^{\text {th }}$ to $18^{\text {th }}$, 2014, Belo Horizonte, MG, Brazil.
} 


\subsection{Use of DRI Fines}

The DRI fines are cold-briquetted in most operating plants. However, the briquettes are generally not strong enough to be sold to an outside market. Sometimes, they cannot be transported even to the adjacent melt shop without excessive breakage.

An alternative to cold-briquetting is melting of the fines in a plasma arc furnace using hollow electrodes. Pilot plant work was carried out by Mintek in South Africa but no industrial scale plant has been built yet.

\subsection{Process Improvements}

In addition to improvements in equipment, for example, more efficient heat exchangers, the following two innovations made DR processes more efficient by increasing production and lowering the costs:

- Natural gas additions in cooling zone, which has resulted in approximately $15 \%$ increase in production with lower gas consumption. The reason for this improvement is the endothermic nature of $\mathrm{CH}_{4}$ decomposition, which produces "free" $\mathrm{H}_{2}$. It is "free" in the sense that the sensible heat of hot DRI supplies the required heat.

- Addition of lime or cement to iron oxide feed, allowing for much higher operating temperatures, thereby increasing productivity and making DRI less reactive.

HyL's Zero Reformer Process is an example of producing all reducing gas in the reactor and ducts. Figure 4 shows a flow sheet of the HyL Zero-Reformer Process. Several Zero-Reformer plants are already in operation, the latest being the Nucor Steel Plant in Convent, La.

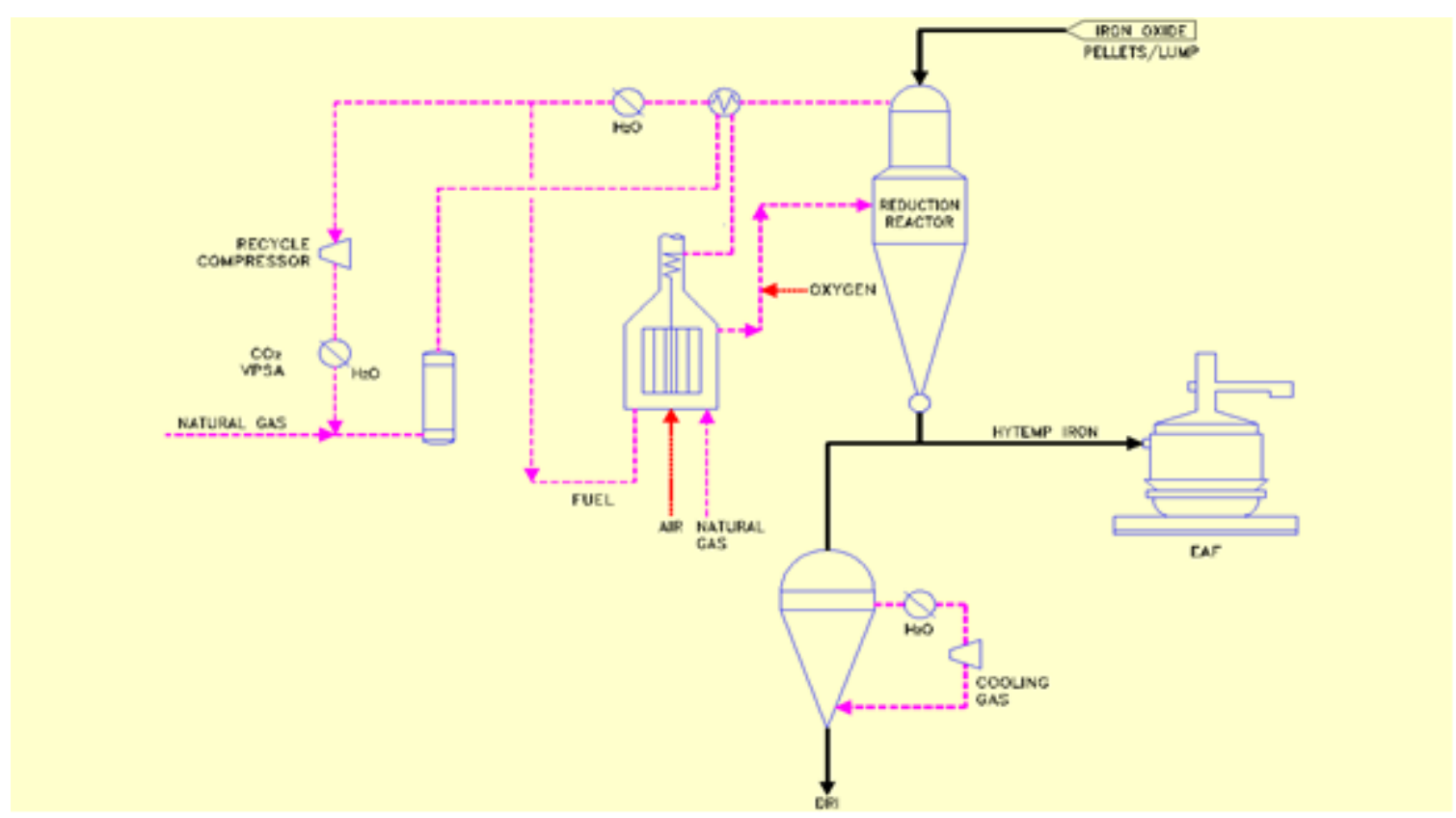

Figure 4: Schematic of HyL Zero-Reformer Plant

A possible route to improving the Midrex Process is by using more of the combustibles, which is approximately $33 \%$ of total off-gas, as reductants. It should be easy to understand that $\mathrm{H}_{2}$ and $\mathrm{CO}$ are much more valuable as redductants than as combustibles. Reforming requires large amounts of heat for the required chemical reactions and sensible heat of the product gases.

A proposed schematic of the improved Midrex process is shown in Figure 5.

\footnotetext{
* Technical contribution to the $44^{\text {th }}$ Ironmaking and Raw Materials Seminar, $15^{\text {rd }}$ Brazilian Symposium on Iron Ore and $2^{\text {nd }}$ Brazilian Symposium on Agglomeration of Iron Ore, September $15^{\text {th }}$ to $18^{\text {th }}$, 2014, Belo Horizonte, MG, Brazil.
} 


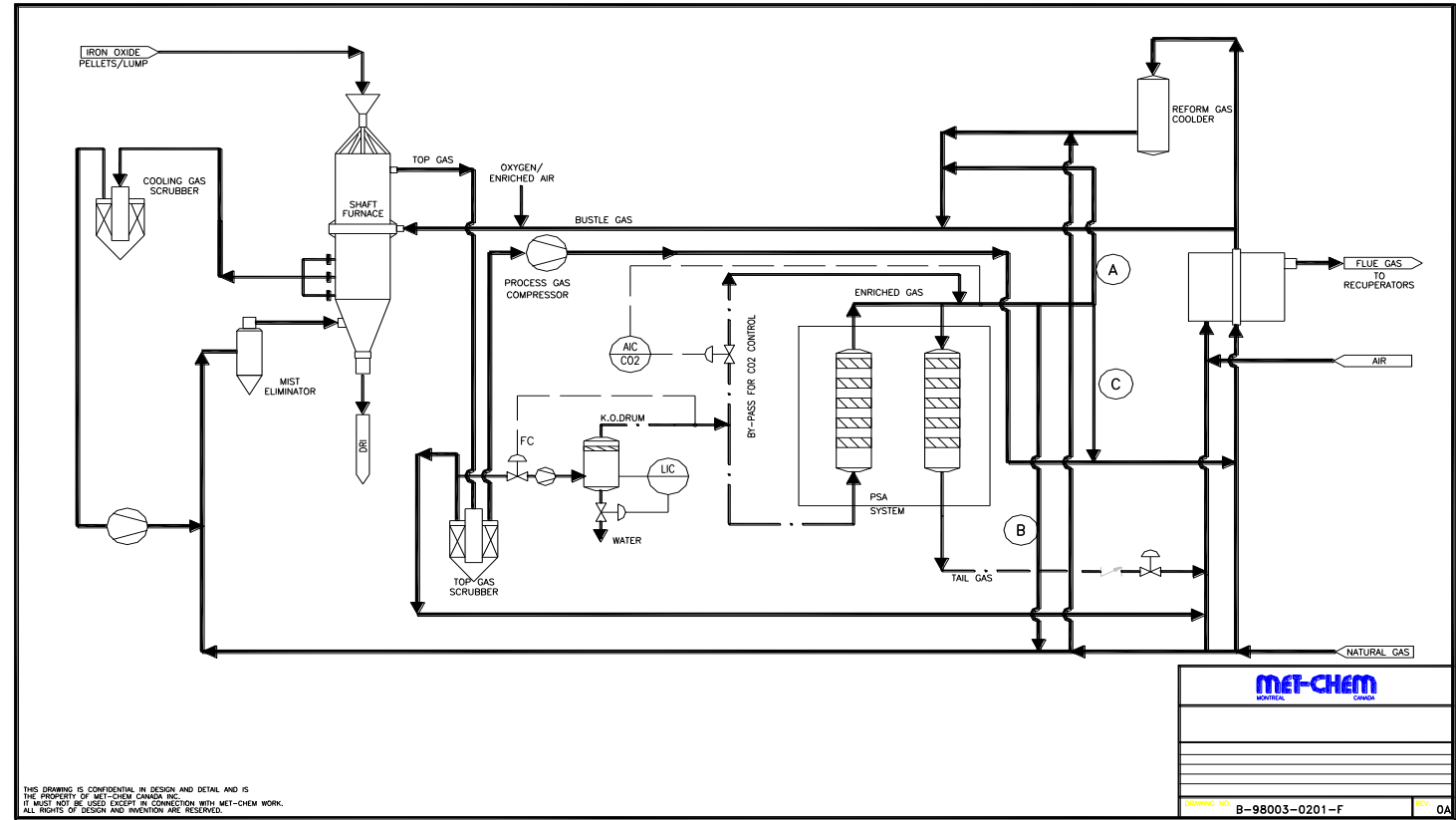

Figure 5: Schematic of a Modified Midrex Plant

\subsection{New Ironmaking Processes [4]}

An interesting process being developed at the University of Utah is flash smelting of taconite fines. The project is sponsored by DOE and some steel mills. The process schematic is shown in Figure 6.

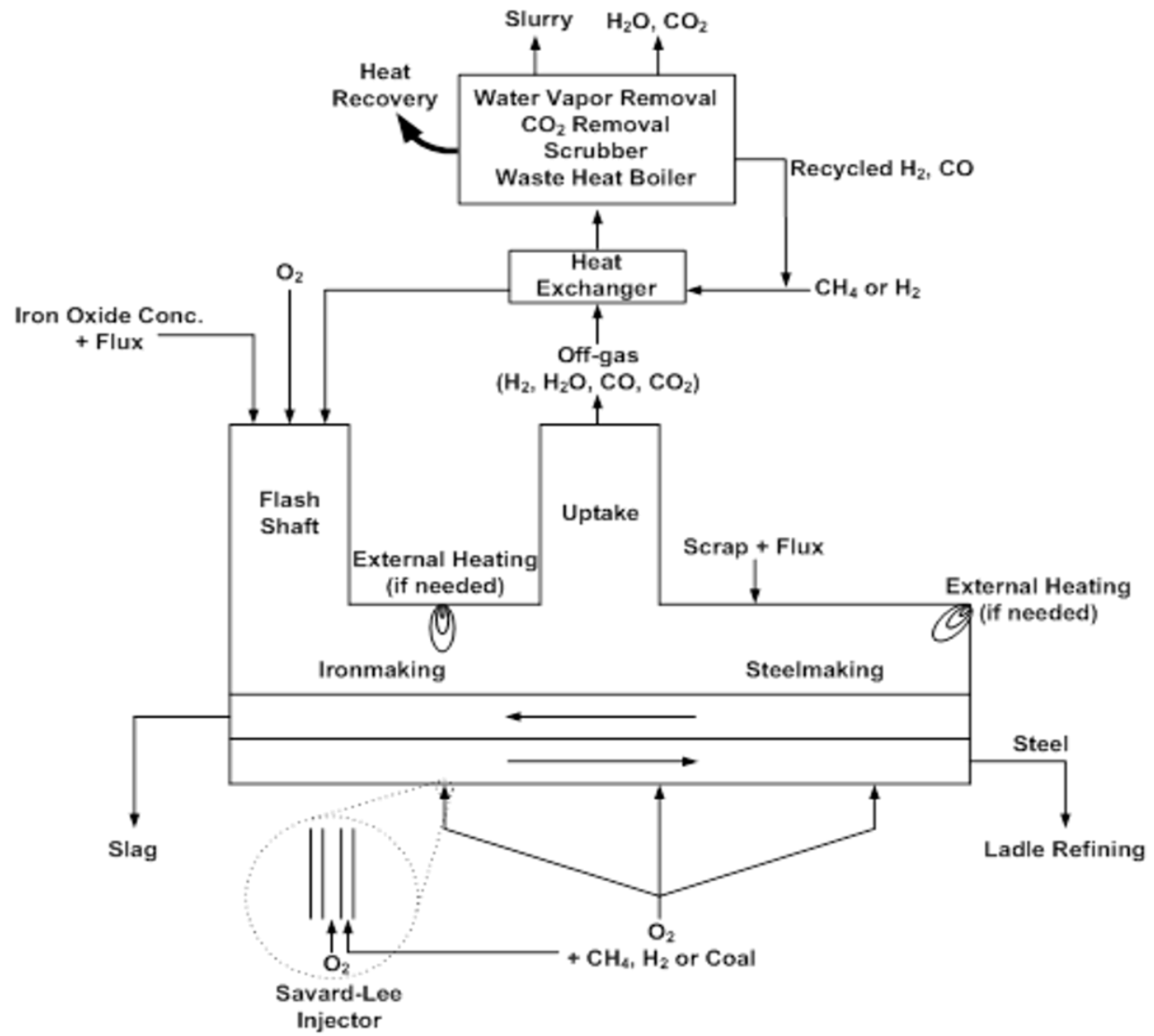

Figure 6: Schematic of Flash Smelting Technology

\footnotetext{
* Technical contribution to the $44^{\text {th }}$ Ironmaking and Raw Materials Seminar, $15^{\text {rd }}$ Brazilian Symposium on Iron Ore and $2^{\text {nd }}$ Brazilian Symposium on Agglomeration of Iron Ore, September $15^{\text {th }}$ to $18^{\text {th }}$, 2014, Belo Horizonte, MG, Brazil.
} 


\section{CONCLUSIONS}

- Depletion of high-quality of iron ores will make it necessary to beneficiate the ores.

- $\quad$ Cooling is generally a bottleneck in many pellet plants and an alternative method proposed is evaporative cooling.

- $\quad \mathrm{DRI} / \mathrm{HBI}$ production will continue to increase, because of the requirement of producing high-quality steel in mini-mills.

- Operation of DR plants at high temperatures and "passivation" of DRI are the main reasons for increasing importance of DRI shipments.

- New ironmaking technologies are being developed but prediction of industrially successful ones cannot be made without results from a demonstration plant.

\section{REFERENCES}

1 BBA Inc., Montreal, Canada KéMag Iron Ore Project, Prefeasibility Study, 2009, 68

2 World Steel Association, Archives (Internet). Disponível em: www.worldsteel.org.

3 Midrex Corporation, World Direct Reduction Statistics 201212

4 Sohnv HY. Novel Ironmaking Technology, TMS Conference 2014

\footnotetext{
* Technical contribution to the 44 $4^{\text {th }}$ Ironmaking and Raw Materials Seminar, $15^{\text {rd }}$ Brazilian Symposium on Iron Ore and $2^{\text {nd }}$ Brazilian Symposium on Agglomeration of Iron Ore, September $15^{\text {th }}$ to $18^{\text {th }}$, 2014, Belo Horizonte, MG, Brazil.
} 